Abstracta Iranicacta Iranica

Revue bibliographique pour le domaine irano-aryen

Volume 24 | 2003

Comptes rendus des publications de 2001

\title{
"The iconography of Pre-Islamic women in Iran ». IA XXXVI, (2001), pp. 1-150.
}

\section{Rémy Boucharlat}

\section{(2) OpenEdition}

1 Journals

\section{Édition électronique}

URL : http://journals.openedition.org/abstractairanica/34289

DOI : 10.4000/abstractairanica.34289

ISSN : 1961-960X

Éditeur :

CNRS (UMR 7528 Mondes iraniens et indiens), Éditions de l'IFRI

\section{Édition imprimée}

Date de publication : 15 mai 2003

ISSN : 0240-8910

\section{Référence électronique}

Rémy Boucharlat, « «The iconography of Pre-Islamic women in Iran ». IA XXXVI, (2001), pp. 1-150. », Abstracta Iranica [En ligne], Volume 24 | 2003, document 58, mis en ligne le 05 janvier 2010, consulté le 25 septembre 2020. URL : http://journals.openedition.org/abstractairanica/34289 ; DOI : https:// doi.org/10.4000/abstractairanica.34289

Ce document a été généré automatiquement le 25 septembre 2020.

Tous droits réservés 


\title{
« The iconography of Pre-Islamic women in Iran ». IA XXXVI, (2001), pp. 1-150.
}

\author{
Rémy Boucharlat
}

1 Dans cet article qui a le volume d'un livre, l'A. offre une impressionnante recension des représentations féminines depuis le Néolithique jusqu'à l'époque sassanide. Vaste entreprise qui aboutit essentiellement à un catalogue. A.D. fait le choix d'inclure les objets sans provenance déterminée, donnée comme «Iran » par le catalogue de Musée ou par le marchand d'antiquités. Par ailleurs, sont inclues quelques représentations dont le sexe est douteux - en particulier pour l'époque achéménide. L'A. applique pour les différentes périodes, quand c'est possible, une même classification mixte: type de support ou iconographie (figurines nues, femmes sur des ustensiles, adorantes, têtes et bustes féminins, femmes des classes supérieures, scènes de banquets, reines et nobles, scènes de la vie quotidienne, scènes érotiques, mère et enfant, famille).

En une page seulement, elle mentionne que la fonction de ces représentations est une question majeure, de même que la provenance exacte (temple, maison, lieu public), information qui pourrait revêtir une réelle importance pour la fonction. Amplifié par plus de reproductions, ce type de catalogue devrait pouvoir constituer une base de données sur support électronique qui le rendrait plus utilisable.

\section{INDEX}

Thèmes : 3.2.2. Pré-Achéménides et Achéménides 
AUTEURS

RÉMY BOUCHARLAT

CNRS - Lyon 